\title{
LES CHRONIQUES DE LANGAGE AND THE DEVELOPMENT OF LINGUISTIC
}

\section{PURISM IN QUEBEC}

\begin{abstract}
The second half of the twentieth century has seen the emergence in Quebec of a number of societies for the protection or promotion of the French language. Since the 1990s, new societies have increasingly been established online, with older ones also creating an online presence. Most of these societies publish journals which appear several times a year. An earlier study (Walsh 2013) ${ }^{1}$ has shown that the type of metalanguage used and the major preoccupations reflected by these societies on their websites and in their journals can be seen to reflect a moderately purist attitude (based on the theoretical framework for evaluating and measuring purism outlined by George Thomas 1991). ${ }^{2}$ This article presents the results of a similar investigation of a sample of Québécois newspaper columns dealing with questions of language which appear regularly in journals and newspapers, known as chroniques de langue, to determine whether the current-day purism displayed by Québécois language societies is reflected in an earlier period.
\end{abstract}

\section{Introduction}

The second half of the twentieth century saw the emergence in Quebec of a number of societies for the protection or promotion of the French language. Since the 1990s, new societies have been increasingly established online, with older ones also creating an online presence. Most of these societies publish journals which appear several times a year. An earlier study (Walsh 2013) ${ }^{3}$ has shown that the type of metalanguage used and the major preoccupations reflected by these societies on their websites and in their journals reflect a purist attitude. This article presents the results of a similar investigation of chroniques de 
langue - newspaper columns dealing with questions of language which appear regularly in journals and newspapers - from the same region but an earlier time period. We may expect this sample of language columns from Quebec to be similar in nature to the material produced by the language societies in Quebec: both are the result of a perception that the language is in some way endangered and a desire to protect the language from that danger. We may also expect differences in the language used and the concerns displayed in the earlier period, given the immense changes in society and in attitudes towards the French language which were brought about by societal change and linguistic legislation from the 1960s on. The study analyses a sample of 200 articles from the ChroQué corpus of language columns, which contains over 8000 articles produced by forty columnists over the period 1865-1996, ${ }^{4}$ taking one hundred texts from two decades at different periods (1880-89 and 1940-49). In particular, the type of metalanguage used and the major concerns of the authors are examined during the course of this article to determine similarities with, and differences from, the language and concerns of current-day language societies.

Before proceeding to a discussion of the study, it is first necessary to outline what we understand by the term 'linguistic purism' and the methods used to measure it. The analysis in this article uses the theoretical framework developed in George Thomas's Linguistic Purism $(1991)^{5}$, 'the first broadly comparative and cross-cultural study of purism', which establishes a theoretical framework outlining the elements typical of all purist movements. ${ }^{6}$ This framework is in the form of a checklist of characteristics, presented in a questionnaire, by means of which he claims we can complete a profile of purism in a given country. ${ }^{7}$ The framework was used in Walsh's $(2013)^{8}$ study of the objectives, attitudes, major preoccupations and type of language used by six language societies for the defence or promotion of the French language in Quebec and showed that these societies display a 
moderately purist attitude. It is applied here to the sample of language columns to determine whether they also reflect a purist outlook.

This article takes the broad definition of purism outlined by Thomas: ${ }^{9}$

the manifestation of a desire on the part of the speech community (or some section of it) to preserve a language from, or rid it of, putative foreign elements held to be undesirable (including those originating in dialects, sociolects and styles of the same language). It may be directed at all linguistic levels, but primarily the lexicon. Above all, purism is an aspect of the codification, cultivation and planning of standard languages.

According to this definition, purism includes ideas which are also common to standardisation and prescriptivism, namely the notion that some elements of language are desirable while others are not. However, purism goes further by introducing the following ideas: only one form of the language is the 'correct' form (generally this form is the standard form); this language is currently pure and, therefore, change to it equals contamination, corruption or decline of some sort; and the language must be protected from this contamination and preserved in its current state (or, alternatively, if the language has already begun to be corrupted, the corrupted part must be removed). Standardisation and prescriptivism do not necessarily share these themes of contamination, protection and preservation. Standardisation, for example, frequently requires change and innovation, particularly during the elaboration stage, and prescriptivism, although it shares with purism the idea that there is only one 'correct' form of the language, is not inherently conservative; prescriptive norms can change.

The article first outlines the context for the study and the sources used. It next provides an analysis of the main preoccupations of, and the metalanguage used in, the sample of language columns chosen and compares this to the preoccupations and metalanguage of the language studies analysed in Walsh $2013 .{ }^{10}$ It then applies Thomas's framework to the results of this analysis to determine whether or not the language columns can be seen to display a purist attitude. Finally, it proceeds to a discussion of the outcomes of this analysis 
and the earlier one to determine where similarities and differences lie and to discuss possible reasons for any changes over time.

\section{Context for the study and sources used}

Walsh $(2013)^{11}$ used language societies as a way of accessing attitudes towards the French language in the present day to determine whether or not they displayed linguistic purism. The aim of the current study is to assess attitudes towards French in the past using the strong tradition of chroniques de langage, language columns in the periodical press dealing with questions of language, which have been published in Quebec since the 1860s. More specifically, chroniques de langage are articles discussing questions relating to language which are produced by a single author and published regularly, generally in the written press (in newspapers and journals). The content of such columns can be very varied, both across different columns/authors and also within a single column. According to Remysen, ${ }^{12}$ who maintains the Québécois corpus of chroniques de langage, ChroQué (from which the sample of articles for this study is taken) and who has published extensively on the topic:

La chronique de langue est un ensemble de discours sur la langue, plus particulièrement encore sur les bons et les mauvais usages de la langue. Elle est diffusée périodiquement sous forme de rubriques dans les médias écrits (articles de journal ou de revue) ou électroniques (émissions de radio ou de télévision). La chronique est signée par une même personne, physique ou morale, à laquelle on reconnaît une compétence en matière de langue.'

These language columns were first studied in the 1970s and they have been used since then to examine various aspects of linguistic attitudes in Quebec such as attitudes towards anglicisms (cf. Bouchard 1989), ${ }^{13}$ linguistic insecurity (cf. Bouchard 1988) ${ }^{14}$ and, more recently, the 'imaginaire linguistique' and the links between language and identity (cf. Wim Remysen $2011 ;^{15}$ 2012). ${ }^{16}$ Studies of the output of individual authors of these articles have also been published (for example, Gagné $2005 ;{ }^{17}$ Laurendeau $2004 ;{ }^{18}$ Prévost 1996). ${ }^{19}$ These articles have not yet been used specifically for a study of linguistic purism, but I suggest that they are particularly useful documents for a study of the development of purism in the past, 
as the tradition of chroniques dates back to at least the mid-19th century, a high number of columns were produced which reached a wide audience ${ }^{20}$ and we know that the attitudes of the intellectual elite who produce them have an important influence on general attitudes towards language. ${ }^{21}$

The first metalinguistic discussion of Canadian French ${ }^{22}$ can be seen in the chroniques de langue published by Michel Bibaud in the journal L'Aurore from 1871, but it was not until 1841, with the publication by Thomas Maguire of the Manuel des difficultés les plus communes de la langue française $e^{23}$ that a metalinguistic discourse really began to emerge. ${ }^{24}$ Bibaud's language columns consisted of short articles condemning the use of anglicisms in specialized vocabulary, in particular legal vocabulary, but the language used by the French speech community more generally in Quebec was not attacked. However, Maguire's Manuel was a corrective volume, aiming to improve the French used generally in Canada, and was based solely upon the French standard as used in France, not accepting any term that was not included in French dictionaries. From this point on, a number of corrective manuals were published, most of which had the intent of removing 'barbarismes', 'expressions vicieuses' and 'fautes' from Canadian French, and a fashion for language columns also began. Between 1865 and 1960, 65 language columns appeared in French-Canadian newspapers, such as $L a$ Presse, La Patrie and Le Droit. These were nearly all concerned with denouncing 'to different degrees the terrible affliction of anglicisms ${ }^{25}$ and also targeted terms specific to Canadian French such as archaisms, regionalisms or neologisms. ${ }^{26}$ For a detailed analysis of the work of various language columnists, see Wim Remysen $2010,{ }^{27} 2011,{ }^{28} 2012 .{ }^{29}$

In order to provide a representative sample of language columns over the period under examination, 100 individual articles have been taken for two ten-year periods between 188089 and 1940-49 from a sample of language columns written by four different authors. 188089 was chosen as the first decade, as this was the decade when the production of language 
columns first really became widespread. ${ }^{30}$ 1940-1949 was chosen as the second decade, because it was in the decades after this time that the 'Quiet Revolution' began to take hold (in particular the 1960s) and linguistic legislation began to be enacted (most importantly in the 1970s) that so changed attitudes towards the French language in Quebec (cf. Bouchard 2002 for a sociolinguistic history of Quebec). ${ }^{31}$

Samples of articles from two language societies for the defence and promotion of the French language which were active in Quebec in the period 2008-2010 were also used (based on Walsh 2013): $:^{32}$ Mouvement estrien pour le français (MEF) and Impératif français. These societies both show an interest in promoting the status of the French language and in protecting the French language from anglicisms or 'incorrect' use. In this latter aim, they display a similar purpose to the language columns which are the focus of the present study.

\section{Major preoccupations and metalanguage displayed in sources}

\subsection{0-1889}

A sample of articles from the language columns of two authors was taken for the period 1880-1889: Alphonse Lusignan and an anonymous author (see appendix for further details). ${ }^{33}$ Lusignan's articles are briefer and less detailed than Anonymous; the former deals with only one issue per article, while the latter generally discusses a number of issues. ${ }^{34}$ Both columns deal mainly with errors in the use of terms or expressions in French. Although both also frequently refer to the use of anglicisms, this remains a side issue to some extent. Of 402 individual comments on various issues, Anonymous mentions anglicisms 58 times, that is in only one in seven of his comments (14.4\%). Although Lusignan mentions them more frequently, they appear in only 18 of 50 comments, that is, in roughly one-third of comments (36\%). The remaining comments all deal with perceived errors in French, and tend to centre on the incorrect use of individual terms or phrases. 


\subsubsection{Anonymous}

In Anonymous' column, the majority of comments focus on the perceived incorrect use of individual terms and phrases in French. For example, in several comments, Anonymous discusses what he sees as the incorrect use of 'au delà': 'Ne dites pas : au delà de 3000 hommes ; mais : plus de 3000 hommes.' (31 December 1880). Other comments discuss the correct use of the terms faire and infliger and the difference between parmi and dans. Occasionally, questions of grammar are dealt with, for example, tense selection : 'Ne dites pas : ce matin, M. Nelson fut choisi comme maire, - mais : ce matin, M. Nelson a été choisi... On n'emploie jamais le passé défini pour raconter un fait du jour même.' (22 January 1881).

Anonymous frequently uses overtly prescriptive forms of language in his comments, including forms such as 'Ne dites pas X, mais Y'; 'Ne parlez pas de X, parler de Y'; and 'À l'expression X, préférez $Y^{\prime}$. This makes it clear to readers that only one form is the correct form, and any other forms are to be avoided. In spite of this prescriptive stance, Anonymous rarely includes any other commentary carrying a value judgment. He occasionally reinforces the use of the prescriptive imperative 'ne dites pas' by stating that a form is incorrect or redundant or that it 'sounds bad', for example, 'La première forme est incorrecte' (7 January 1881) or 'La première expression ... sonne d'une manière peu gracieuse' (11 March 1881). However, he only very rarely makes any clearly negative value judgements and does not make use of any imagery associated with purist discourse in other contexts (e.g. choking weeds, disease, contagion etc.).

Anonymous occasionally states that a certain term or expression 'n'est pas français', and as this can indicate both anglicisms and other French 'errors', itt would appear that it can mean both 'incorrect' French and literally 'not' French (i.e. foreign), although it most often means the latter. However, in general, when discussing anglicisms or usages influenced by English (in particular loan translations and semantic loans), Anonymous makes no reference 
to foreign influence and does not indicate that it is because of its status as an anglicism that the term or expression is to be avoided. Indeed, of the 58 comments which deal with anglicisms, only ten overtly refer to the foreign nature of the term or expression in question, namely by stating in each case that the usage 'n'est pas français'. He does not state what he means by 'français', and although one may assume that it means the standard French of France, he does not explicitly state this at any stage, nor does he mention any dictionaries or grammars.

\subsubsection{LUSIGNAN Alphonse}

Lusignan is less overtly prescriptive than Anonymous and uses fewer expressions of the type 'Dites ... ne dites pas', although expressions such as 'il fallait dire', 'il faut dire' and 'on a tort de dire' appear in just over two-fifths of the comments examined (44\%). He otherwise presents his articles simply and without negative value judgments, only explicitly referring to something being a 'faute' on three occasions. Similarly to Anonymous, those comments dealing with perceived errors in Canadian French tend to focus on individual terms and phrases in French, for example, the correct use of the terms 'jalousies' and 'persiennes' (6 October 1884) or the difference between 'résidence' and 'demeure'/'domicile' (11 November 1884). He occasionally touches upon issues such as gender, pronunciation or spelling but does not go into any level of detail in any of his articles, and does not touch on more complex points of grammar at any point. He is more overtly negative towards anglicisms than Anonymous, however, , in particular, loan translations and semantic extensions. He employs more clearly negative language to describe their use, for example, 'un anglicisme féroce' (16 May 1884) or 'voilà un affreux anglicisme' (1 August 1884).

Lusignan is also unclear about the standard he is adhering to. He alludes to the French of France only once ('en France on emploie le mot exposition de préférence', 9 April 1885), and at no stage does he discuss the standard language or directly allude to the variety 
of French he is recommending to readers. However, he references French dictionaries such as Littré more than once and this would suggest that it is indeed the standard French of France which he is using as a model. He also occasionally describes Canadian-French speakers in a disparaging manner, for example, 'Le Canadien traduit trop littéralement et fait des néologismes impardonnables' (16 October 1884), and refers to usages specific to Canada being incorrect, which leads one to suppose that French elsewhere (for example, in France) is not.

On the evidence of these two language columns, then, it would appear that, at this period in time, there is a greater concern with adherence to prescriptive norms, and with a standard form of French, than with anglicisms. Although this standard is not explicitly named, it would appear that both authors are implicitly referring to the standard French of France.

\section{2. $\quad 1940-1949$}

A sample of articles from the language columns of two authors was taken for the period 1940-1949: Alfred Carrier and the Société du parler français au Canada (henceforth SPFC). Samples were taken from two different SPFC columns 'Corrigeons-nous !' (B) and 'Corrigeons-nous !' (C) (column B was published as a series of leaflets, column C appeared in Le Canada français, see Appendix A for more detail). Again, there is a difference in the length and style of the two language columns, In general, the SPFC's articles are briefer and less detailed than Carrier's; the latter generally goes into great detail (3-4 pages) on one issue, while in the former, the majority of articles in column B either deal with two to three issues per article or provide lists of terms to avoid with their recommended replacements. The articles in column $\mathrm{C}$ are somewhat longer, but number only 8 in total. The SPFC deals with both general French 'errors' (terms or expressions that do not conform to prescriptive norms, frequently French-Canadian usages or archaisms) and anglicisms, while Carrier's column 
deals almost exclusively with perceived errors in French and only extremely rarely discusses anglicisms.

\subsubsection{CARRIER Alfred}

In his column, Carrier goes into some detail about various questions of usage and grammar, in particular discussing the 'correct' use of various terms, expressions and parts of speech (frequently discussing written style and points of spelling/abbreviation etc.). In these discussions, he invariably refers to prescriptive manuals and dictionaries and also to the French of France to reinforce the points that he is making, and he also not infrequently goes into the history of a term or phrase. For example, in his first article, Carrier deals with the use of the article with proper names, and during the course of his discussion, makes reference to three prescriptive works, including a grammar book produced by the Frères des Écoles Chrétiennes, ${ }^{35}$ the Grammaire Larousse $d u$ XXe Siècle ${ }^{36}$ and the second volume of Geoffrion's Zigzags autour de nos parlers $^{37}$ (an earlier language column) (24 September 1942). In an article discussing the correct abbreviation of the term comté (as in the regional county municipality, Le compté $d u$ Lac-St-Jean), he describes France as 'notre pays d'origine' and goes on to refer to prescriptive manuals to support his argument, including, again, a grammar book produced by the Frères des Écoles Chrétiennes (15 October 1942). ${ }^{38}$ He returns frequently to this grammar in further articles. Other grammars referred to include the Grammaire de la langue française par une reunion de professeurs (F.E.C.). ${ }^{39}$ the Grammaire de l'Académie $;^{40}$ the Grammaire française instantanée.$^{41}$ Dictionaries include the Petit Larousse illustré ${ }^{42}$ the Nouveau Larousse illustré ${ }^{43}$ the Larousse universel ${ }^{44}$ the Larousse pour tous,${ }^{45}$ the Littré $;{ }^{46}$ and the Dictionnaire de l'Académie. ${ }^{47}$ Of all the language columns examined, Carrier's deals with grammatical issues in the most detail. It also makes the most frequent mention of prescriptive guides. Such wide-ranging intertextual references may well allow him to increase his authority, but they also make his prescriptive intent very 
clear, as do comments such as the following: 'Nous ne devrions jamais nous défaire de nos livres de classe. Nous devrions principalement conserver la grammaire que nous avons apprise sur les bancs de l'école et en relire de temps à autre une page' (9 September 1943).

He refers, in this column, to the uncertainty of correct usage, due to the variation portrayed in various newspapers, journals and books in Quebec: 'nous sommes submergés par le flot de doute et de l'incertitude, ballottés d'une rive à l'autre sans que nous sachions à laquelle nous agripper' (29 October 1942). He compares this to the conformity found in France, and uses this as an argument in favour of using the French of France as the standard to follow: 'Comment expliquer que livres, journaux et revues, en France, s'accordent à suivre ainsi la même ligne de conduite ? D'où vient cette unanimité ? N'est-ce pas parce que c'est l'usage, le BON usage ?' (29 October 1942). He frequently refers to 'usage' being the arbiter of correctness, stating that 'Pour nous, les humbles et les profanes, nous n'avons qu'à nous incliner devant ce maître inexorable qu'est l'usage' (19 November 1942) and that 'c'est l'usage qui est le grand maître dans les questions de langage' (28 December 1944). However, his point of reference appears always to be usage in France, rather than that in Canada. He makes this clear when he says 'Dans les questions de langue, l'Usage est notre maître souverain à tous. Bien entendu, l'usage suivi en France quand il s'agit de la langue française.' The importance for him of following the norms of the French used in France is perhaps because he believes that 'ce n'est certes pas l'usage suivi de ce côté-ci de l'Atlantique qui va régir les destinées de la langue française' (4 May 1944).

\subsubsection{Société du parler français au Canada}

The sample of articles from the SPFC's language column is very clearly prescriptive in tone. Indeed, the majority of the articles (30 out of 50) consist simply of two opposing columns of terms, one labelled 'Ne dites pas' and the other 'Mais dites'. The remaining twenty articles 
enter into a more detailed description of terms or expressions, but generally aim to encourage the use of one term while discouraging the use of another, usually the term used in France. Indeed, it quickly becomes clear to the reader that the main aim of the column (during the period examined) is to align usage in French Canada with the standard French of France. Prescriptive formulations are frequently used, for example, 'il faut employer $\mathrm{X}$ '; 'l'expression propre est X'; 'on devrait éviter d'employer X'; 'le bon usage prohibe X', 'il est incorrect de dire X'. Most of the more detailed articles in the sample make reference to the French used in France, nearly always in order to recommend the replacement of an anglicism or a French-Canadian term by the French one, using phrases such 'ne s'emploie guère en France'; 's'appelle en France'; 'porte en France le nom'; and 'suivant l'usage établi en France'. French usage is also frequently talked about in a positive tone. For example, ' $\mathrm{X}$ reste aujourd'hui la manière la plus française et la plus élégante' (Corrigeons-nous ! Vol. 30, $\mathrm{n}^{\circ}$ 02), and references are made to the Académie française and its dictionary or to other French dictionaries.

In the articles composed of the two opposing lists of terms, 'Ne dites pas' and 'Mais dites', there is no discussion or reasoning behind the condemnation of one term and recommendation of the other, but all of the terms to avoid are either anglicisms or French Canadian terms and the recommended terms are in common use in France. Condemned usages include, for example, regional terms such as char (wagon, voiture) in its various combinations (char à bagages, char à malle, char parloir etc., Corrigeons-nous ! nº 47) and archaisms such as champelure/chamtepleure $\left(\mathrm{n}^{\circ} 48\right)$. Condemned anglicisms are generally either unassimilated loanwords, such as barley ( $\left.\mathrm{n}^{\circ} 29\right)$ and socket ( $\left.\mathrm{n}^{\circ} 45\right)$; assimilated loanwords, such as baloné ( $\left.\mathrm{n}^{\mathrm{o}} 29\right)$ and pepermanne ('peppermint') ( $\left.\mathrm{n}^{\mathrm{o}} 35\right)$; or loan translations, such as au meilleur de ma connaissance $\left(\mathrm{n}^{\circ} 65\right)$; and maison semi-détachée $\left(\mathrm{n}^{\mathrm{o}}\right.$ 74). 
The SPFC displays a generally negative attitude towards anglicisms. This is often shown by the use of a simple prescriptive expression, such as those outlined above but references are also made to French-Canadians using anglicisms too often, for example, 'Encore un mot anglais que nous employons trop souvent' (Corrigeons-nous ! $\mathrm{n}^{\mathrm{o}} 23$ ), and more strongly negative comments are also sometimes employed, for example, 'Le tour de phrase [...], tour emprunté de l'anglais, est fautif et d'une lourdeur extrême' (Corrigeonsnous ! Vol. 30, $\mathrm{n}^{\mathrm{o}}$ 03). Occasionally, a direct allusion to the assumed negative qualities of those who use too many anglicisms is made, for example, 'Même nos gens instruits [...] se servent de plusieurs mots anglais, sans doute parce qu'ils ne connaissent pas la traduction, peut-être aussi par snobisme du mauvais aloi' (Corrigeons-nous ! Vol. 30, $\mathrm{n}^{\mathrm{o}}$ 03). The verb 'commetre' lends an air of criminality to the use of anglicisms in phrases such as 'Un joueur de cartes qui discarte commet un anglicisme' (Corrigeons-nous ! Vol. 31, $\mathrm{n}^{\mathrm{o}}$ 01) and 'On ne pourrait pas, sans commettre un anglicisme, se servir des mots anxieux ou anxiété pour signifier désir' (Corrigeons-nous ! Vol. 32, $\mathrm{n}^{\mathrm{o}}$ 06).

On the evidence of these two language columns, then, it would appear that at this period in time there is a continuation of the concern with the adherence to prescriptive norms (very explicitly standard French norms) and the avoidance of anglicisms displayed in the earlier period. However, the prescriptive norm to which readers are expected to adhere has now become very explicitly the standard French norm. This was not made explicit in the earlier sample (1880-89).

\section{3. $\quad 2008-2010$}

A sample of articles for the period 2008-2010 was taken for MEF and Impératif français. Impératif français produces a journal, Ensemble ${ }^{48}$ which is available free of charge on its website.. Although MEF does not produce a journal, its concerns are clearly 
represented in the numerous articles it publishes on its website. A sample of 100 articles was taken from Ensemble for the three-year period 2008-2010 and from MEF's website to discern the main areas of preoccupation of these societies. In addition, both societies devote parts of their website to information on anglicisms in French and the 'correct' use of French. These display many similarities to language columns, as their titles show: a section of MEF's website is devoted to Les mots qu'il faut ${ }^{49}$ and Impératif français publishes a series of notes on language in its Chronique linguistique. ${ }^{50}$ These sections were also analysed.

Analysis of the journal articles showed that the articles produced by the two societies mainly deal with the issue of the marginalization of the French language in Quebec due to the widespread use of English. This fear is discussed generally, rather than manifesting itself in a preoccupation with anglicisms, which are discussed in only a minority of articles. For example, many articles suggest reasons for this marginalisation, such as, for example, the supposed collusion of political and industrial 'elites' who are seen to actively encourage anglicization or the continued weakening of Bill 101 due to its lack of enforcement (Walsh 2013: 136-38). Both MEF's Les mots qu'il faut and Imperatif francais' Chronique linguistique are made up of lists of anglicisms to be avoided and incorrect French or errors to be avoided. In its discussions of 'errors', MEF concentrates largely on the correct use of certain French terms (e.g. the difference between valable and valide; the correct use of the terms civique and civil) and does not touch upon issues of spelling or grammar at all. Impératif français discusses capitalization and points of punctuation and spelling but also concentrates heavily on the correct use of particular French terms. ${ }^{51}$

In terms of the metalanguage used by these societies, both tend towards a subjective and emotive use of language, where a strong correlation between language and national identity is made. For example, MEF claims that 'Langue française et identité québécoise sont inséparables. Sauvegarder l'une c'est sauvegarder l'autre' ${ }^{52}$ and that 'Une langue est d'abord 
une patrie. C'est en elle et par elle que se soudent la solidarité nationale, le vouloir-vivre ensemble et la communauté de destin. ${ }^{53}$ Impératif français asserts that 'la langue française [...] est le signe le plus significatif de notre identité nationale' ${ }^{54}$ Both societies also occasionally use images of war and colonization, imagery which is commonly associated with purist discourses. MEF refers to 'La nouvelle Gestapo intellectuelle qui interdit l'usage des langues autres que l'anglais dans la communication scientifique internationale', ${ }^{55}$ and Impératif français compares the battle to promote the French language to a war needing an army:

pouvez-vous nous assurer, que celles et ceux qui devront toujours lutter pour la promotion et la protection de la langue de Molière, à Montréal, pourront compter sur un chef d'Armée, pour ce faire ? On n'a rarement vu une armée triompher, lorsqu'il n'y avait pas de Général pour diriger les troupes. ${ }^{56}$

\section{Thomas's theoretical framework}

Having examined the contents of each of the four columns and the three language societies, the theoretical framework developed by Thomas will now be used to assess the types and level of purism present in these. Using the same framework as Walsh (2013) ${ }^{57}$ makes it possible to compare the language columns to the language societies and thereby examine the evolution of purist discourses in Canada over the course of 130 years from 1880 to 2010.

The questionnaire devised by Thomas is in the form of a checklist composed of eighteen questions. A simplified version of this checklist, representing only those parts of the framework that are relevant to the discussion, is reproduced in Figure $1 .{ }^{58}$ In addition to the questionnaire, a numerical index which allows a quantitative measure of the intensity of the purism that exists in a given community is reproduced in Figure 2. The numerical index allows us to measure the weighting of non-puristic factors (this corresponds to question one in the questionnaire), the configuration of puristic orientation (this corresponds to questions two to nine), and the targets of purism (questions ten and eleven), and preferred replacements 
(question twelve). As bench-marks for measuring the puristic profile of a situation, Thomas uses the terms mild, moderate and extreme and, depending on what is being measured, he outlines the criteria for deciding which bench-mark to use. Each bench-mark is also assigned a value on his scale (mild purism is assigned 1-2 on the scale, moderate 3-4 and extreme 5). ${ }^{59}$ Where there are two values, non-borderline cases are given the lower value ( 1 for mild purism, 3 for moderate purism) and borderline cases are given the higher value (borderline mild-moderate 2, borderline moderate-extreme 4).

1. To what extent does the purism take non-puristic concerns into consideration in developing its ideology? Not at all To some extent To a great extent

2. Is the puristic orientation external or internal?

External Internal Both

3. If both, which orientation is the dominant one?

External Both equal Internal

4. If the threat is wholly or partially external, which of the following describes the threat more clearly? Non-specific Specific

5. If specific, is more than one language involved?

Yes $\quad$ No

6. If 'No', which of the following describes the language most closely?

From the same diasystem $\quad$ Related Unrelated

7. Which of the following best describes the position of the threatening language(s) vis-à-vis the language where the purism is located?

In the same state In another state

8. Has the threatening language ever served as a language of culture for the speakers of the language where purism is involved?

Yes No

9. If the threat is internal, which planes and which poles are involved?

élitist ethnographic : archaising reformist 
10. Is the purism primarily or exclusively directed at the lexical level?

Yes

No

11. If 'Yes' and the lexical purism is xenophobic, into which of the categories given in Figure 10 (1991: 172) do the targets fall?

Mild $\quad$ Moderate $\quad$ Extreme

12. Similarly, into which of the categories given in Figure 11 (1991: 173) do the preferred replacements fall? Mild $\quad$ Moderate Extreme

Figure 1 Simplified checklist of characteristics for a single instance of purism

\begin{tabular}{|c|c|c|c|c|c|}
\hline \multirow[b]{2}{*}{$\begin{array}{l}\text { Intensity } \\
\text { Level }\end{array}$} & \multicolumn{4}{|c|}{ Intensity criterion } & \multirow[b]{2}{*}{ Average } \\
\hline & $\begin{array}{l}\text { a) Weighting of } \\
\text { non-puristic } \\
\text { factors }\end{array}$ & 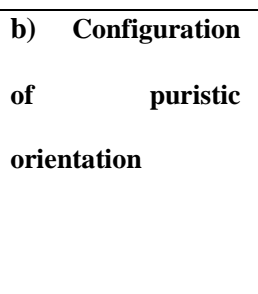 & $\begin{array}{l}\text { c) Targets of } \\
\text { purism }\end{array}$ & $\begin{array}{l}\text { d) Preferred } \\
\text { replacements }\end{array}$ & \\
\hline \multirow[t]{2}{*}{ MILD } & 1 & 1 & 1 & 1 & \\
\hline & 2 & 2 & 2 & 2 & \\
\hline \multirow[t]{2}{*}{ MODERATE } & 3 & 3 & 3 & 3 & \\
\hline & 4 & 4 & 4 & 4 & \\
\hline EXTREME & 5 & 5 & 5 & 5 & \\
\hline SCORE & & & & & \\
\hline
\end{tabular}

Figure 2 Simplified numerical index of puristic intensity

\subsection{Purist and non-purist concerns}

The first question asks to what extent the purism takes non-puristic concerns into consideration in developing its ideology. Thomas argues that non-puristic concerns are motivated by instrumental (i.e. practical) and ethical attitudes, and puristic concerns are motivated by affective, traditionalist and nationalist attitudes. All linguistic behaviour can be seen to be motivated in some way by one or more of these attitudes. ${ }^{60}$ With regard to purist and non-purist concerns, Thomas states that mild purism assigns equal importance to purist 
and non-purist concerns; moderate purism makes some concessions to non-purist concerns; and extreme purism does not take non-purist concerns into account at all. ${ }^{61}$ Affective attitudes include an opposition to foreign influences on the native language; traditional attitudes are based on a reverence for custom (for example, a wish to keep the language in an unchanged, traditional form); and nationalist attitudes are based on the idea that the national culture is unique and irreplaceable and only the national language can adequately serve as a symbol of self-identification with this culture. ${ }^{62}$ Instrumental attitudes are based on practical criteria, with the aim of achieving some goal, and ethical attitudes are based on the inclusion of the whole speech community. ${ }^{63}$ An example of an ethical attitude, according to Thomas, is the 'intelligibility argument', which is used to claim that language elements unknown to the broad masses should be avoided as they hamper intelligibility for a large part of the speech community. ${ }^{64}$

If we now use this question to examine the discourse of the language columns, we see that both Lusignan and Anonymous display purist concerns in their columns; they show an affective attitude in their opposition to English influence and a traditionalist attitude in their desire to avoid 'errors' or, what we may see as deviations from a traditionally 'pure' or 'correct' French, which both authors clearly feel has become tainted over time in Canada. The SPFC also displays both an affective and a traditionalist attitude, whereas Carrier displays a very strong traditionalist attitude only. We might also argue that Carrier displays a somewhat nationalist attitude, given his very clear belief that only the French language of France can adequately serve as the national language of Quebec, and his reference to France as 'notre pays d'origine'. However, this will not change the outcome of the analysis, as this is also a purist consideration. None of the columns show any perceptible non-purist concerns, for example, that avoiding the use of a particular term will aid comprehension. It may be that the authors feel that using only those terms which are in accepted use in France will aid 
comprehension between Canadian-French and French speakers; if this is the case, none of them state so explicitly and we cannot take this for granted. According to Thomas's model, therefore, all of the columns examined display extreme purism and can be assigned a 5 on Thomas's index.

The two language societies examined also all display an affective attitude, as both oppose the use of English. They also make extremely strong links between the French language and Québécois identity, thereby displaying a nationalist attitude (although one that is very different to that shown by Carrier, whose national sentiment is for France rather than Quebec). They therefore base their ideology on at least one purist concern. Although neither society can really be argued to display any instrumental concerns, the ethical concern to allow the integration of the whole speech community is clearly shared by both. It is one of their main aims in ensuring the promotion, as well as the protection, of the French language. They therefore base their ideology on at least one non-puristic concern alongside two puristic concerns and can be seen to display moderate purism (3 on Thomas's index).

\subsection{Orientation of purism}

Questions two to nine concern the orientation of the purism. Thomas makes a general distinction between 'external' purism and 'internal' purism. 'External' (or 'xenophobic') purism involves 'removing or replacing foreign elements, whether their source is specified (targeted xenophobia) or unspecified (general xenophobia)'. ${ }^{65}$ 'Internal' purism includes archaising and reformist purism, which have a temporal basis, and ethnographic and elitist purism, which have a social basis. Archaising purism typically involves 'an attempt to resuscitate the linguistic material of a past golden age, an exaggerated respect for past literary models, and excessive conservatism towards innovations', ${ }^{66}$ whereas reformist purism makes 'a conscious effort to reform, regenerate, renew or resuscitate a language' and is important in the creation of standard languages (ibid.). Ethnographic purism favours rural dialects as a 
source of new words, as these are seen as being in some way purer than the standard language ${ }^{67}$ Elitist purism, on the other hand, is negative towards these rural dialects or any non-standard speech, and is based on the belief that language can be perfected. ${ }^{68}$ With regard to the orientation of the purism, extreme purism is characterised by a combination of xenophobic purism with two internal orientations, moderate purism by a combination of xenophobic purism with one of the internal orientations ${ }^{69}$ and mild purism by either xenophobic purism or one of the internal perspectives. ${ }^{70}$

Both Lusignan and Anonymous display external and internal purism. The former is aimed very clearly at the use of anglicisms in French and the latter is a form of élitist purism, encouraging the use of 'good' (i.e. standard) French. Both authors display the internal orientation more strongly, however, giving more space in their columns to issues internal to the French language. The same is true of the SPFC. These can be said display moderate purism, therefore, showing a combination of external purism with one internal orientation, and can be assigned a 3 on Thomas's index. Carrier displays internal purism only, a very strong form of élitist purism and must therefore be said to display mild purism in this regard, with a value of 1 on Thomas's index. The orientation of MEF and Impératif français is also both external and internal and all therefore display a moderate level of purism, with a value of 3 on Thomas's index.

\subsection{Targets and replacements of purism}

Question ten refers to the linguistic level on which the purism takes place. Thomas claims that examples of purism can be found on all linguistic levels (phonological, morphological, syntactic, lexical and orthographic), but makes a distinction between unmarked purism, operating at the lexical level, and marked purism, operating at the levels of smaller or larger linguistic segments; he thus views lexical purism as archetypal. ${ }^{71}$ In Walsh 2013, this view is strongly reinforced. ${ }^{72}$ It is certainly the case that the majority of targets in all of the language 
columns are lexical; although they also deal occasionally with issues in orthography, pronunciation (phonology) and occasionally word formation (morphology) and sentence formation (syntax , e.g. negation), the vast majority of articles deal with individual words. This is also the case for the language societies.

Question twelve concerns the types of word which are targeted by the external lexical purism and question thirteen the replacements of these targets. Thomas's model has been adapted here, as the original lacked clarity. ${ }^{73}$ In the adapted framework, in terms of the targets of lexical purism, mild purism is directed at loanwords from unrelated languages; moderate purism at loanwords from related languages, and internationalisms; and extreme purism at calques (loan translations, loan renditions and semantic loans). In terms of the replacements, mild purism is characterised by the acceptance as replacements of internationalisms, unassimilated loanwords from related and unrelated languages and assimilated loanwords from unrelated languages. Moderate purism is characterised by the rejection of these, but the acceptance of assimilated loanwords from related languages, loan translations, loan renditions, semantic loans and loan creations. Extreme purism is characterised by the acceptance as replacements either existing native language terms or loan renditions and loan creations in the absence of other types of replacement, which are rejected. That is, while moderate purism accepts other types of calque and assimilated loanwords in addition to loan renditions and loan creations, extreme purism accepts loan renditions and loan creations only and rejects any other type of calque or loanword.

In each sample of articles examined, the anglicisms discussed and the replacements suggested have been analysed and categorized according to the typology outlined in Walsh $2013 .{ }^{74}$ Figure 3 shows the proportion of different categories targeted in the language columns. It is worth noting that Carrier's column is excluded here because targets and replacements refer to external purism only. Anonymous mainly targets calques in his column: 
loan translations and semantic loans make up $95 \%$ of targets. He therefore displays extreme purism here and can be assigned a 5 on Thomas's index. The majority of Lusignan's targets are also calques: loan translations and semantic loans account for $61 \%$ of all targets. However, assimilated and unassimilated loanwords make up nearly two-fifths of the total (39\%). Although, according to Thomas, targeting calques shows extreme purism, targeting loanwords from unrelated languages shows mild purism. It is difficult to assign a level of extreme purism to Lusignan's column for this reason; equally, it cannot be said to display mild purism. Given that the majority of targets are calques, this can be classed as a borderline moderate-extreme case, and given a value of 4 on the numerical index. Conversely, the SPFQ's column largely targets unassimilated and assimilated loanwords (66\%), while calques account for only $34 \%$ of targets. This can therefore be seen as a borderline mildmoderate case and assigned a 2 on the numerical index.

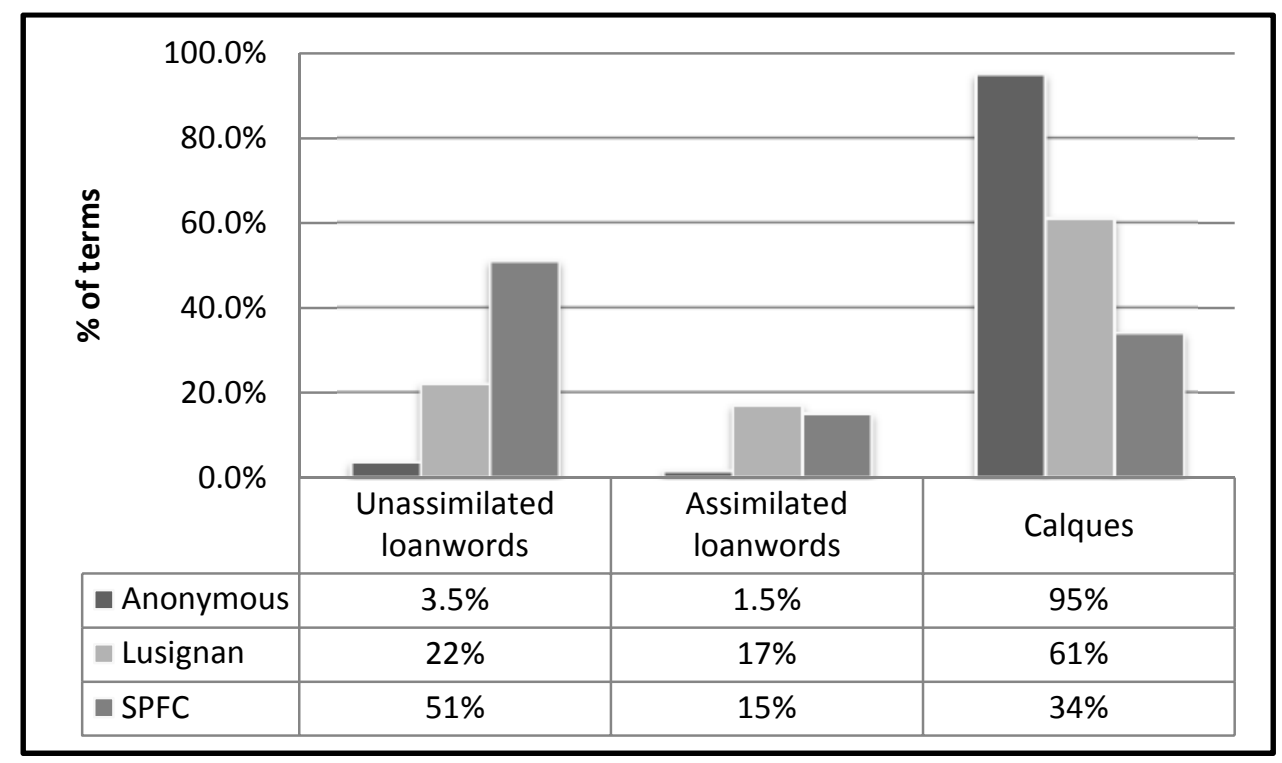

Figure 3 Language column targets

Figure 4 shows the proportion of different categories targeted in the language societies. 50 terms were taken from Impératif français and 40 from MEF. A fair proportion of the terms targeted by Impératif français and MEF are unassimilated loanwords $(42 \%$ and $43 \%$, respectively) although the majority of targets are calques (52\% and 50\%, respectively) 
(Walsh 2013: 133-34). For this reason, we can classify them as borderline cases and give them a value of 4 on the numerical index.

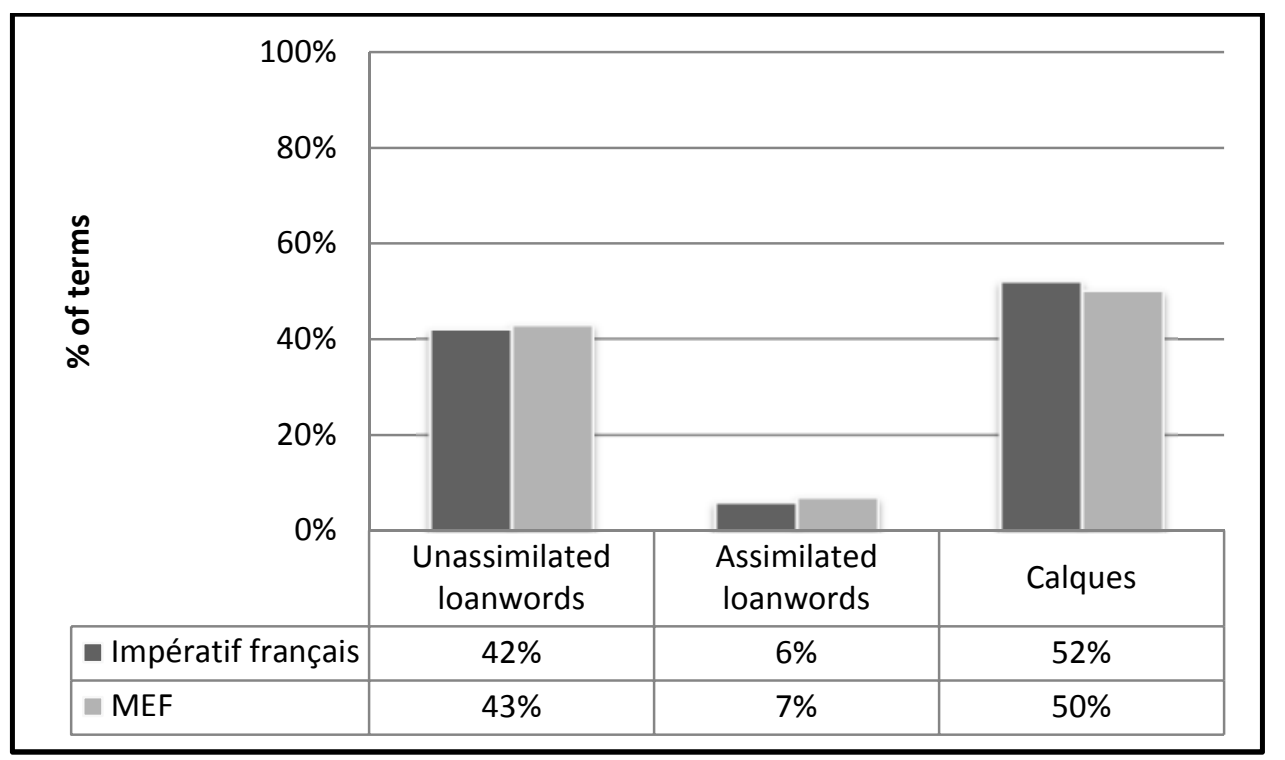

Figure 4 Language society targets

Figure 5 shows the replacements suggested for the anglicisms targeted by the language columns. In all three cases, the majority of replacements are existing French terms. Accepting existing French terms as replacements only happens in cases where an anglicism is competing for use with an existing French term with the same meaning. We can assume that allowing both terms to coexist as synonyms would indicate a mildly purist attitude. Insisting upon the complete removal of the anglicism and the exclusive use of the French term, however, reflects a non-compromising position which must be seen as extreme purism. Both Anonymous and APFQ can be assigned a 5 on Thomas's index. Although Lusignan does accept some assimilated loanwords as replacements, by far the majority are existing French terms and it is therefore reasonable to assign him a 5 also. 


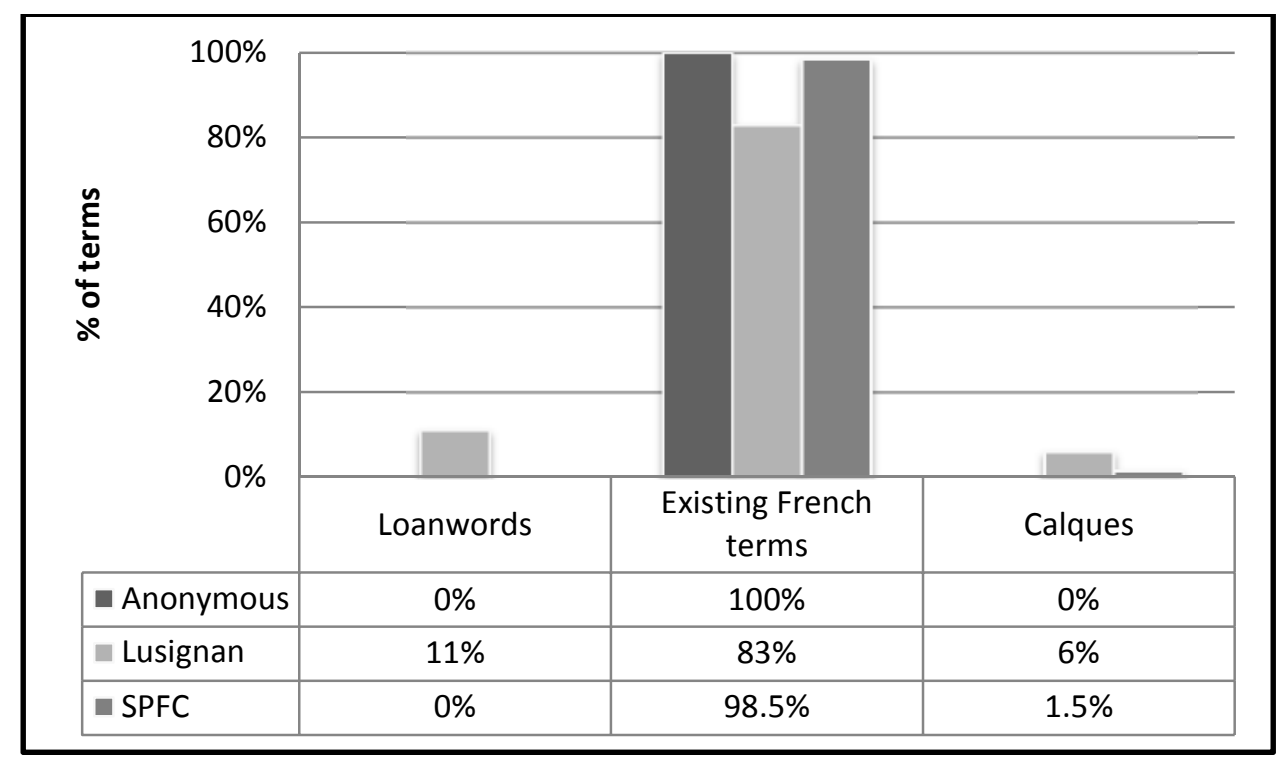

Figure 5 Replacements of language columns

Figure 6 shows the replacements suggested by the language societies. While MEF mainly chooses existing French terms as replacements (90\%), Impératif français also suggests some calques (12\%) and loan creations (18\%). MEF clearly displays extreme purism here (5 on Thomas's index), whereas Impératif français can be seen to represent a borderline case between moderate and extreme purism (4 on Thomas's index).

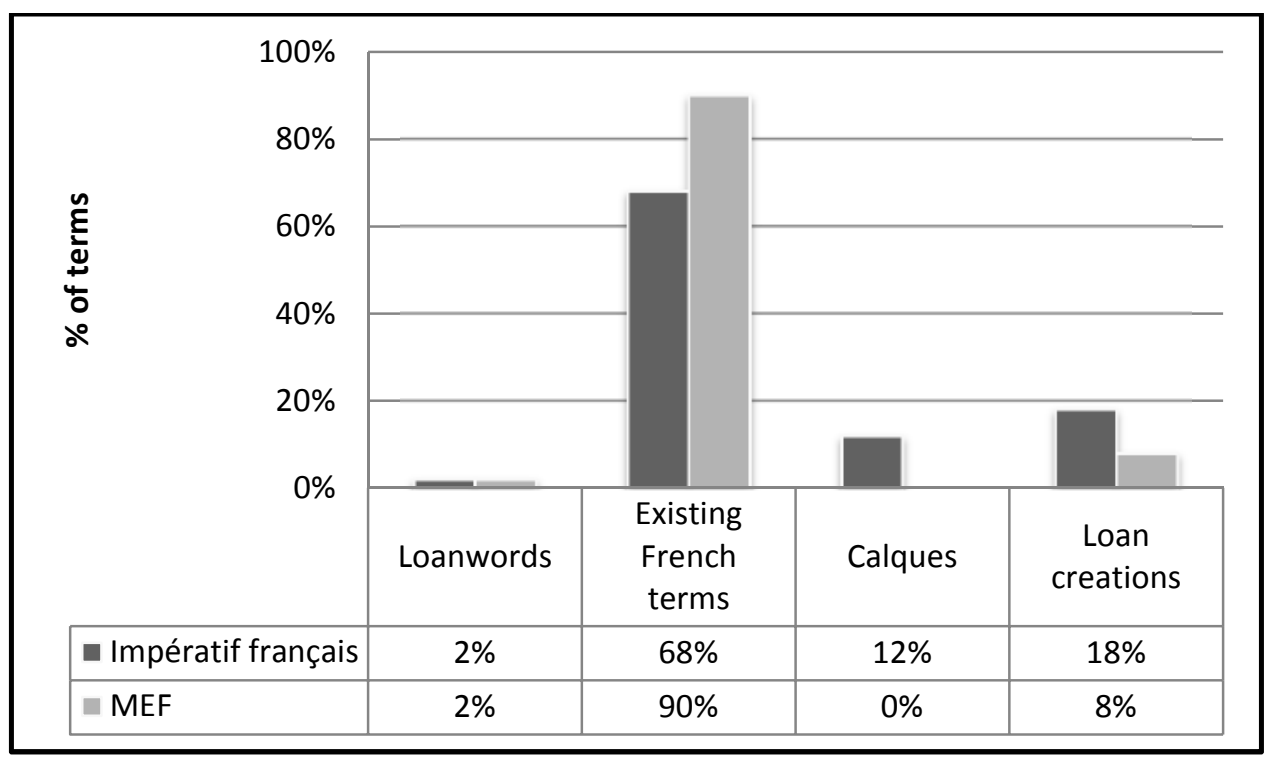

Figure 6 Language society replacements

Presenting the values for all of the language columns and the language societies sideby-side in Figure 7, we can see that Anonymous and Lusignan's columns are the most purist, 
displaying moderate-extreme purism with average values of 4.5 and 4.25 , respectively. Carrier and the SPCF's columns display moderate purism with average values of 3 and 3.75. The language societies Impératif français and MEF also display moderate purism, with average values of 3.5 and 3.75 , respectively.

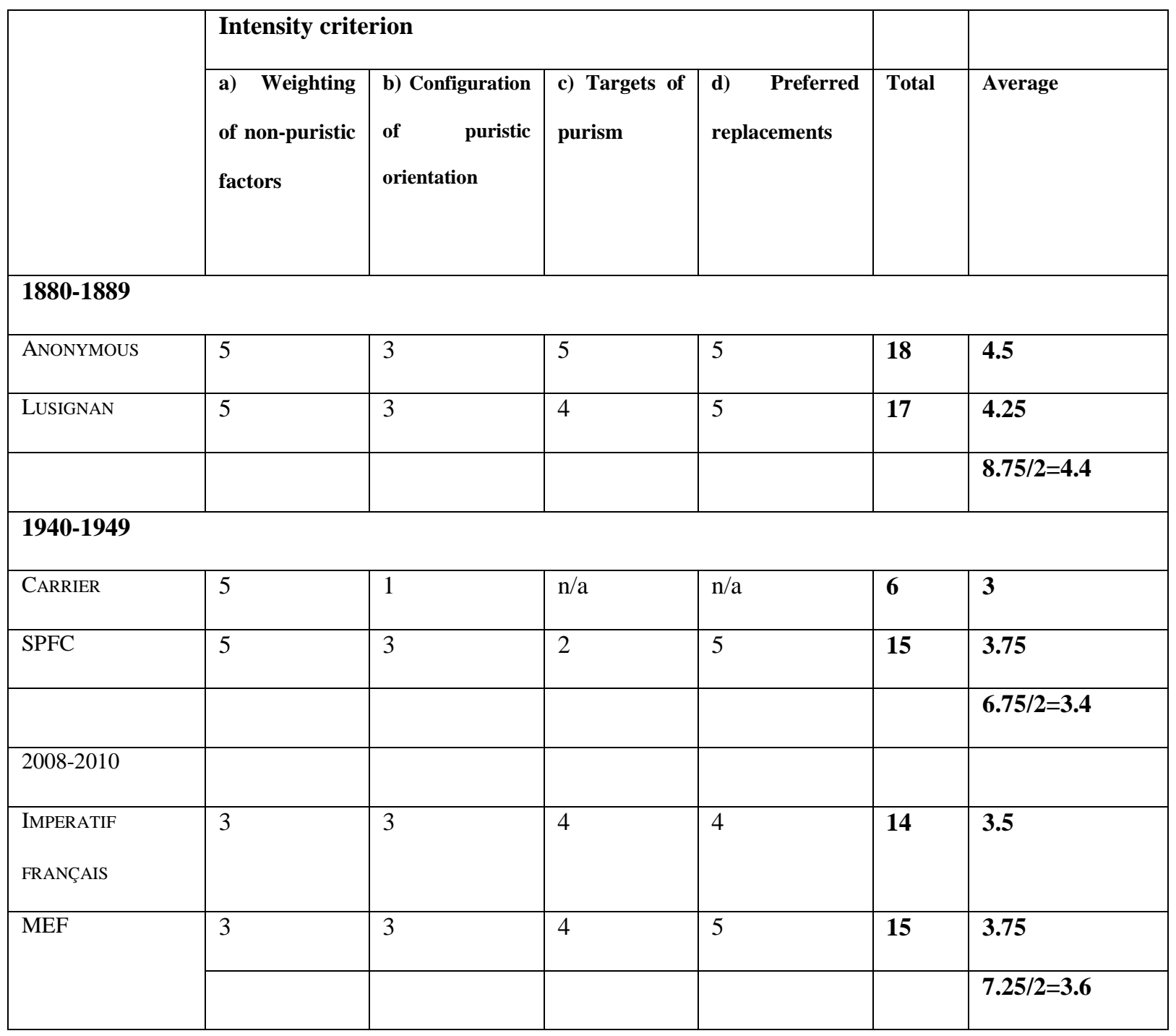

Figure 7 Puristic intensity of language columns

Using the numerical index as a guide, it is difficult to note any major differences in the levels of purism over the three periods examined. However, as we shall see in the conclusions below, the analysis has highlighted some differences between the three periods. This raises an issue with the model. The average values displayed by the numerical index for the language societies and the language columns for the period 1949-1949 are identical, and 
yet the purism displayed by two show some clear differences, as we have seen. This suggests that relying on the index alone to provide a picture of purism in a given situation may cause a misleading assessment of that situation. However, the numerical index does provide a useful support to a qualitative analysis of purism. It is not intended to be looked at in isolation from this analysis, but rather to act as an additional means of comparison.

\section{Conclusion}

Both the earlier and later samples of articles from language columns examined display a clear preoccupation with adherence to prescriptive norms and the influence of English on the French language in Quebec, as do the modern day language societies. However, the analysis has highlighted some differences between the three periods, and in particular, between the two earlier periods 1880-1889 and 1940-1949 and the modern-day period. This may reflect a change in attitudes over time.

Firstly, the results show that the earlier language columns (1880-1889) are more purist overall, with the later language columns (1940-1949) and language societies displaying a more moderate level of purism. The earlier language columns are particularly purist in the type of anglicisms that they target. Loan translations and semantic loans (calques) are much less noticeable than assimilated or unassimilated loanwords. Indeed, Thomas argues that calques may be tolerated where loanwords from the same language are not, perhaps because calques, even those consciously created to replace loanwords, are not clearly foreign, and can pass unnoticed by many (indeed, perhaps even most) speakers. ${ }^{75}$ However, he also notes that some purists may see calques as being more dangerous even than loanwords, as their assimilation into the native system may cause a threat to the system in some way. ${ }^{76}$ For this reason, Thomas sees them as a useful test of the level of purism: 'Indeed, precisely because of their compromising nature, calques offer an excellent litmus test of the intensity of puristic 
feeling' ${ }^{77}$ It would appear from this that puristic feeling was more intense in 1880-1889. The fact that both sets of language columns display more purist concerns in their ideology than the language societies, of which two also display non-purist concerns and, specifically, a desire to ensure the integration of the whole speech community, may also suggest a higher level of purism in earlier times (both 1880-1889 and 1940-1949).

A second, more striking, change between the earlier periods and the modern period is the difference in emphasis laid on the French of France. A concern for Québécois French to adhere to the prescriptive norms of the standard French of France is rarely, if ever, mentioned by the language societies. There could be a number reasons for this. It may be, for example, that the introduction of Bill 101 and the subsequent transformation of society in Quebec and increased status of French has led to a reduction in the linguistic insecurity felt by speakers of Canadian-French, at least insecurity relating to adherence to an external prescriptive norm. Further evidence for this argument can arguably be seen in the notable difference in the amount of space devoted to the 'correct' use of French and the avoidance of anglicisms in the sources used. The former is clearly of far higher importance in earlier times. In the language columns examined for the period 1880-1889, the use of anglicisms remains a side issue, with the majority of comments dealing with perceived errors in French. Similarly, during the period 1940-1949, Carrier's column deals exclusively with perceived errors in French and the SPFC's column places roughly equal value on the latter and discussions of anglicisms. The language columns also all make a higher use of prescriptive language than the language societies and make far more frequent reference to dictionaries, usage guides and grammers. Although the language societies include some lists of the type 'ne dites pas ... mais dites', the majority of articles in their journals and on their websites do not employ a very highly prescriptive tone, nor do they refer to dictionaries or grammars. The language columns, on the other hand, makes it very clear to the reader that one variety of French is acceptable and 
one variety only, the French of France; although they do not directly use purist themes of corruption or contamination, there is no doubt that they feel that this language has become corrupted by local French-canadian terms or anglicisms and that it is necessary to remove and replace the corrupted parts. There is far less concern with prescriptive norms in the modernday societies and no apparent preoccupation with the French of France. It could be argued, therefore, that the introduction of Bill 101 and the subsequent transformation of society in Quebec and increased status of French has led to a reduction in the linguistic insecurity felt by speakers of Canadian-French, an insecurity which is so clearly portrayed by the concern to avoid regionalism or archaisms shown by language columnists in the periods $1880-1889$ and 1940-1949 and yet far less evident in the modern-day language societies. Now that French has become a majority language in Quebec, used in the workplace as well as in the home, it may be that the need to adhere to an outside 'prestige' standard is diminished.

On the other hand, this change may equally be due to the fact that, in spite of the transformative changes brought about by Bill 101, for modern-day language societies in Quebec the issue of the influence of English on French has become ever more pressing and urgent. It is possible that the threat to the continued existence of the French language in Quebec is felt by the language societies to be so great that they see little point in concerning themselves with the quality of the language. A concern with prescriptive norms is likely to remain a minor consideration, as long as speakers feel threatened by a more powerful language, namely English. Although this threat already existed in the late nineteenth century and first half of the twentieth century, the increasing influence and power of the United States since the second World War in global economic, political and cultural spheres and the increase in the use of English as an international language led to a corresponding decline in the use of French, which has arguably increased the feeling of threat from the English language in Quebec. In the current day, the prevalence of English on the internet and the fact 
that it is the working language of most international companies has no doubt exacerbated this fear, in spite of the far-reaching and transforming changes effected by Bill 101.

In summary, this study has shown that linguistic purism in French Canada has changed over the years, moving from a preoccupation with internal 'correctness' and adherence to the standard French of France and a minority interest in anglicisms, to a much reduced concern with the internal structure of the language or adherence to any external standard and a much greater concern with the influence of English on French. This may suggest that the implementation of linguistic legislation such as the far-reaching Bill 101 in Quebec has led to a decrease in the linguistic insecurity felt by French-Canadian speakers or at least a move away from insecurity based on lack of adherence to an external norm. Equally, the increased threat from the English-speaking world in political social and cultural arenas as well as the linguistic one may simply have concentrated the focus of those concerned with defending the language onto this threat, thereby reducing the amount of time and space they give to internal prescription. A much broader study examining a wider range of language columns over more periods in time is now necessary to allow us to determine more clearly the reasons for such a change.

\section{Appendix A}

\begin{tabular}{|l|l|l|}
\hline Decade & Author & Language column \\
\hline 1880-1889 & Alphonse Lusignan (50 articles) & 'Fautes à corriger : une chaque jour', \\
& & $\begin{array}{l}\text { La Patrie, Montréal } \\
{[50 \text { articles from a total of } 219 .} \\
\text { Column published between } 28 \text { April } \\
1884 \text { and 13 July 1885] }\end{array}$ \\
\cline { 3 - 4 } & & 'Incorrections de langage relevées \\
\cline { 2 - 4 } & Anonymous (50 articles) & \\
\hline
\end{tabular}




\begin{tabular}{|c|c|c|}
\hline & & $\begin{array}{l}\text { dans les journaux', Le Courrier } d u \\
\text { Canada, Québec } \\
\text { [50 articles from a total of } 59 \text {. Column } \\
\text { published between } 17 \text { December } 1880 \\
\text { and } 2 \text { October } 1882 \text { ] }\end{array}$ \\
\hline 1940-1949 & $\begin{array}{l}\text { Société du parler français au Canada } \\
\text { (50 articles) }\end{array}$ & $\begin{array}{l}\text { 'Questions de français', Le Progrès de } \\
\text { Saguenay, Chicoutimi } \\
\text { [50 articles from a total of } 188 . \\
\text { Column published between } 24 \\
\text { September } 1942 \text { and } 12 \text { December } \\
\text { 1946] } \\
\text { 'Corrigeons-nous!', leaflet printed by } \\
\text { the Société du parler français au } \\
\text { Canada, Université Laval, Quebec } \\
\text { [42 articles from a total of } 85 \text {. Column } \\
\text { published between February } 1930 \text { and } \\
\text { June 1945] } \\
\text { 'Corrigeons-nous!', Le Canada } \\
\text { français, Quebec } \\
\text { [8 articles from a total of } 8 \text {. Column } \\
\text { published between September } 1942 \\
\text { and September 1945] }\end{array}$ \\
\hline
\end{tabular}

${ }^{1}$ Olivia Walsh, Linguistic purism in France and Quebec (PhD thesis, University of Cambridge, 2013).

${ }^{2}$ George Thomas, Linguistic Purism (London: Longman, 1992).

${ }^{3}$ Walsh, Linguistic purism in France and Quebec.

${ }^{4}$ ChroQué <http://catfran.flsh.usherbrooke.ca/chroque/> 


\footnotetext{
${ }^{5}$ Thomas, Linguistic Purism.

${ }^{6}$ Thomas, Linguistic Purism, p. 2.

${ }^{7}$ Thomas, Linguistic Purism, p. 191-193.

${ }^{8}$ Walsh, Linguistic purism in France and Quebec.

${ }^{9}$ Thomas, Linguistic Purism, p. 2.

${ }^{10}$ Walsh, Linguistic purism in France and Quebec.

${ }^{11}$ Ibid.
}

${ }^{12}$ Wim Remysen, (2005) 'La chronique de langage à la lumière de l'expérience canadienne-française : un essai de définition', in Les Journées de linguistique: Actes du 18e colloque 11-12 mars 2004, ed. by Julie Bérubé, Karine Gauvin et Wim Remysen (Québec, Centre interdisciplinaire de recherches sur les activités langagières, 2005), pp. 267-281 (pp. 270-71).

${ }^{13}$ Chantal Bouchard, 'Une obsession nationale: l'anglicisme', Recherches sociographiques, 30:1 (1989), 67-90.

${ }^{14}$ Chantal Bouchard, 'De la «langue du grand siècle » à la a « langue humiliée » : les Canadiens français et la langue populaire, 1879-1970', Recherches sociographiques, 29:1 (1988), 7-21.

15 Wim Remysen, 'L'Application du modèle de l'imaginaire linguistique à des corpus écrits: le cas des chroniques de langage dans la presse québécoise', Langage et société, 135 (2011): 47-65.

${ }^{16}$ Wim Remysen, 'Les représentations identitaires dans le discours normatif des chroniqueurs de langage canadiens-français depuis le milieu du XIXe siècle', French Language Studies, 22 (2012): 419-44.

${ }^{17}$ Frédérick Gagné, 'Louis Fréchette et la langue française au Canada : étude linguistique de sa chronique de langage', in Les Journées de linguistique: Actes du 18e colloque 11-12 mars 2004, ed. by Julie Bérubé, Karine Gauvin et Wim Remysen (Québec, Centre interdisciplinaire de recherches sur les activités langagières, 2005), pp. 283-293.

${ }^{18}$ Paul Laurendeau, 'Un remarqueur Canadien de l'entre deux-guerres', in Les Remarqueurs sur la langue française du XVI siècle à nos jours, ed. by Philippe Caron (Rennes: Presses Universitaires de Rennes, 2004), pp. 211-235.

${ }^{19}$ Geneviève Prévost, 'Les Chroniques de langage d'Étienne Blanchard (1883-1952): Aperçu des préoccupations normatives d'une époque au Canada', Cahiers de lexicologie, 68 (1996-I): 175-192.

${ }^{20}$ Wim Remysen, (2005) 'La chronique de langage à la lumière de l'expérience canadienne-française : un essai de définition', in Les Journées de linguistique: Actes du 18e colloque 11-12 mars 2004, ed. by Julie Bérubé, Karine Gauvin et Wim Remysen (Québec, Centre interdisciplinaire de recherches sur les activités langagières, 2005), pp. 267-281 (p. 267).

${ }^{21}$ Chantal Bouchard, La Langue et le nombril. Une histoire sociolinguistique du Québec (Saint-Laurent, Quebec: Fides, 2002).

${ }^{22}$ The use of the term Québécois is problematic in an article that takes a diachronic approach. The term Québécois has really only been in widespread use since the 1960s. Before this, French speakers in the area were generally referred to as Canadiens français. Although this may appear to have a broader geographical reach than the term Québécois, in fact, it mainly referred to French speakers from the province of Quebec (cf. Remysen 2009). For this reason, the term 'French Canadians' will be used throughout the article when discussing the language columns from 1880-1889 and 1940-1949.

${ }^{23}$ Thomas Maguire, Manuel des difficultés les plus communes de la langue française, adapté au jeune âge, et suivi d'un recueil de locutions vicieuses (Quebec: Fréchette \& Cie., 1841).

${ }^{24}$ Chantal Bouchard, La Langue et le nombril. Une histoire sociolinguistique du Québec (Saint-Laurent, Quebec: Fides, 2002), p. 207.

25 'tous dénoncent à des degrés divers la terrible maladie des anglicismes', Paul Daoust, 'Les Chroniques sur la langue', in Le Français au Québec: 400 ans d'histoire et de vie, ed. by Michel Plourde (Quebec: Fides; Publications du Québec, 2000), p. 200.

${ }^{26}$ Chantal Bouchard, 'Anglicisation et autodépréciation', in Le Français au Québec: 400 ans d'histoire et de vie, ed. by Michel Plourde (Quebec: Fides; Publications du Québec, 2000), pp. 197-205 (p. 198).

${ }^{27}$ Wim Remysen, 'Les représentations identitaires dans le discours normatif des chroniqueurs de langage canadiens-français depuis le milieu du XIXe siècle', French Language Studies, 22 (2010): 419-44.

${ }^{28}$ Wim Remysen, 'L'Application du modèle de l'imaginaire linguistique à des corpus écrits: le cas des chroniques de langage dans la presse québécoise', Langage et société, 135 (2011): 47-65.

${ }^{29}$ Wim Remysen, 'Les représentations identitaires dans le discours normatif des chroniqueurs de langage canadiens-français depuis le milieu du XIXe siècle', French Language Studies, 22 (2012): 419-44.

${ }^{30}$ Between 1865, when language columns first began to appear, and 1880 only seven articles appeared.

${ }^{31}$ Chantal Bouchard, La Langue et le nombril. Une histoire sociolinguistique du Québec (Saint-Laurent, Quebec: Fides, 2002). 
${ }^{32}$ Four further associations are discussed in Walsh 2013: Association des usagers de la langue française (Asulf), Ligue internationale des scientifiques pour l'usage de la langue française, Mouvement Québec français and Société Saint-Jean-Baptiste de Montréal. For reasons of space, and also because most are more concerned with the promotion of French - that is, with its continued use - and are not concerned with issues internal to the language - that is, with its lexis or grammar - they are not discussed here.

${ }^{33}$ Hereafter referred to as Anonymous.

${ }^{34}$ Although there may be methodological problems with comparing two language columns that differ so broadly in length, the two columns chosen for comparison in the decade 1940-49 display a similar disparity in length. As we are attempting to analyse differences/similarities across time, it was more important to choose two columns in each decade which showed similarities and were therefore easily comparable, than to choose two columns which were similar in length within each decade.

${ }^{35}$ Frères des Écoles Chretiennes, Grammaire française élémentaire: suivi d'une méthode d'analyse grammaticale raisonné: a l'usage des écoles chrétiennes (Tours: Mame, 1845).

${ }^{36}$ Grammaire Larousse du XXe Siècle, ed. by Félix Gaiffe et al. (Paris: Larousse, 1936).

${ }^{37}$ Louis-Philippe Geoffrion, Zigzags autour de nos parlers : simples notes, vol. 2, (Québec: published by the author, 1924-1927).

${ }^{38}$ Frères des Écoles Chretiennes, Grammaire française élémentaire.

${ }^{39}$ Réunion de professeurs, Grammaire abrégée de la langue française (Tours/Paris: Mame/De Gigord, 1936).

${ }^{40}$ Académie française, Grammaire de l'Académie française (Paris: Firmin-Didot et Cie., 1932).

${ }^{41}$ Louis Rolland, Grammaire française instantanée. Cours moyen. Certificat d'études. Dictionnaire orthographique et grammatical avec 4 tableaux synoptiques (Paris: L. Pommeret, 1933).

${ }^{42}$ Petit Larousse illustré, ed. by Claude Augé (Paris: Larousse, 1906-1923).

${ }^{43}$ Nouveau Larousse illustré, ed. by Claude Augé, 8 vols (Paris: Larousse, 1897-1904).

${ }^{44}$ Larousse universel en deux volumes : nouveau dictionnaire encyclopedique, ed. by Claude Augé (Paris: Larousse, 1922).

${ }^{45}$ Larousse pour tous, ed. by Claude Augé (Paris: Larousse, 1910).

${ }^{46}$ Émile Littré, Dictionnaire de la langue française (Paris: Hachette, 1876).

${ }^{47}$ Académie française, Dictionnaire de l'Académie française, 2 vols, 8th edition (Paris: Hachette, 1932-35).

${ }^{48}$ Bulletin Ensemble d'Impératif français <http://www.imperatif-

francais.org/bienvenu/telechargements/bulletinensemble-d-imperatif-francais.html> [accessed June 2010]

${ }^{49} \mathrm{MEF}$, "Les mots qu'il faut" < http://www.mef.qc.ca/les_mots_qu_il faut2.htm> [accessed February 2010]

${ }^{50}$ Impératif français, "Chronique linguistique" < http://www.imperatif-francais.org/bienvenu/imperatif-

francais/chronique-linguistique/> [accessed June 2010]

${ }^{51}$ Walsh, Linguistic purism in France and Quebec, pp. 132-36.

${ }^{52}$ MEF, "Mémoire du MEF aux États Généraux du français" < http://www.mef.qc.ca/memoire-MEFfrancais\%20\%28commission\%29.htm> [accessed February 2010]

${ }^{53} \mathrm{MEF}$, "Le combat de la langue est prioritaire pour l'indépendance nationale"

$\langle$ http://www.mef.qc.ca/combat_de_la_langue_prioritaire.htm> [accessed February 2010]

${ }^{54}$ Impératif français, "Loi 101: « tout va très bien madame la marquise "” <http://www.imperatif-

francais.org/bienvenu/a-vous-la-parole/2008/loi-101-tout-va-tres-bien-madame-la-marquise.html > [accessed June 2010]

${ }^{55} \mathrm{MEF}$, "Le Français, une langue pour la science" <http://www.mef.qc.ca/francais-langue-science.htm>

[accessed February 2010]

${ }^{56}$ Impératif français, "Pour lutter, il faut un chef d'armée" < http://www.imperatif-francais.org/bienvenu/a-vousla-parole/2009/pour-lutter-il-faut-un-chef-d-armee.html> [accessed June 2010]

${ }^{57}$ Walsh, Linguistic purism in France and Quebec.

58 Thomas, Linguistic Purism, pp. 191-92.

${ }^{59}$ Ibid. p. 171.

${ }^{60}$ Ibid. pp. 35-37.

${ }^{61}$ Ibid. p. 171.

62 Ibid. p. 43.

${ }^{63}$ Ibid. p. 37.

${ }^{64}$ Ibid. p. 49.

${ }^{65}$ Ibid. pp. 80-81.

${ }^{66}$ Ibid. p. 79.

${ }^{67}$ Ibid. p. 77.

${ }^{68}$ Ibid. pp. 78-79.

${ }^{69}$ Ibid. p. 171.

${ }^{70}$ Walsh, Linguistic purism in France and Quebec, p. 90. 
${ }^{71}$ Thomas, Linguistic Purism, pp. 62-66.

${ }^{72}$ Walsh, Linguistic purism in France and Quebec.

${ }^{73}$ For a detailed discussion of how and why the model was adapted, and a classification of loanwords as used in the adapted framework, see Walsh 2013.

${ }^{74}$ Walsh, Linguistic purism in France and Quebec. In each case, all anglicisms used each column were included in the analysis: 58 in Anonymous, 18 for Lusignan and 139 for APFQ. Given the differences in length and outlook of the different language columns, it was unfortunately impossible to obtain a more directly comparable sample. Percentages are used to display the relative proportion of each type of anglicism targeted to allow for a more easy comparison.

${ }^{75}$ Thomas, Linguistic Purism, p. 23.

${ }^{76}$ Ibid. p. 71.

${ }^{77}$ Ibid. p. 106. 